$\begin{array}{ll} & \text { Etnográfica } \\ \text { etnográfica } & \text { Revista do Centro em Rede de Investigação em }\end{array}$

Antropologia

vol. 25 (3) | 2021

Vol. 25 (3)

\title{
Arte urbana, poderes públicos e desenvolvimento territorial: uma reflexão a partir de três estudos de caso
}

Urban art, public authorities and territorial development: a reflection from three case studies

Ricardo Campos, José Luís Abalos Júnior e Otávio Raposo

\section{(2) OpenEdition}

\section{Journals}

\section{Edição electrónica}

URL: https://journals.openedition.org/etnografica/10747

DOI: $10.4000 /$ etnografica. 10747

ISSN: 2182-2891

\section{Editora}

Centro em Rede de Investigação em Antropologia

\section{Edição impressa}

Data de publição: 1 outubro 2021

Paginação: 681-706

ISSN: 0873-6561

\section{Refêrencia eletrónica}

Ricardo Campos, José Luís Abalos Júnior e Otávio Raposo, «Arte urbana, poderes públicos e desenvolvimento territorial: uma reflexão a partir de três estudos de caso», Etnográfica [Online], vol. 25 (3) | 2021, posto online no dia 29 outubro 2021, consultado o 08 janeiro 2022. URL: http:// journals.openedition.org/etnografica/10747 ; DOI: https://doi.org/10.4000/etnografica.10747

\section{(c) (7) \&}

Etnográfica is licensed under a Creative Commons Attribution-NonCommercial 4.0 International License. 


\section{Arte urbana, poderes públicos e desenvolvimento territorial: uma reflexão a partir de três estudos de caso}

Ricardo Campos, José Luís Abalos Júnior e Otávio Raposo

Este artigo surge a partir de diferentes pesquisas desenvolvidas recentemente pelos seus autores, que versam a arte urbana e a sua relação com a cidade contemporânea. De especial relevância é o enfoque conferido à articulação entre a arte urbana e os poderes públicos locais, naquilo que podemos definir como políticas para a arte urbana. Nas últimas duas décadas vem-se trilhando um caminho que aponta, precisamente, para um certo consenso relativamente ao papel e à importância da arte urbana, que passa por processos claros de legitimação e institucionalização. Neste artigo pretendemos debater estas questões a partir de pesquisas realizadas em contextos geográficos distintos. As pesquisas, de índole qualitativa e etnográfica, foram desenvolvidas nos últimos anos, centradas em empreendimentos emblemáticos desenvolvidos nas cidades de Lisboa e Loures (Portugal) e de Porto Alegre (Brasil). As conclusões revelam uma tendência para entender a arte urbana do ponto de vista estratégico e utilitário, considerada como um instrumento relevante para a produção da paisagem urbana.

PALAVRAS-CHAVE: arte urbana, graffiti, cidade, etnografia urbana, poder local.

Urban art, public authorities and territorial development: a reflection from three case studies - This article comes from different researches recently developed by its authors, which deal with urban art and its relationship with the contemporary city. Of particular relevance is the focus on the articulation between urban art and local public authorities in what we can define as policies for urban art. In the last two decades, a path has been taken that points precisely to a certain consensus regarding the role and importance of urban art, which goes through clear processes of legitimation and institutionalization. In this article we intend to discuss these issues from research carried out in different geographical contexts. The research, of qualitative and ethnographic nature, was developed in the last years, centered in emblematic urban art projects developed in the cities of Lisbon and Loures (Portugal) and Porto Alegre (Brazil). The conclusions reveal a tendency to understand urban art from a strategic and utilitarian point of view, considered as a relevant instrument for the production of the urban landscape.

KEYWORDS: urban art, graffiti, city, urban ethnography, local power. 
CAMPOS, Ricardo (rmocampos@yahoo.com.br) - CICSNova, Nova FCSH, Universidade Nova de Lisboa, Portugal.

ABALOS JÚNIOR, José Luís (abalosjunior@gmail.com) - Programa de Pós-Graduação em Antropologia Social, UFRGS, Brasil.

RAPOSO, Otávio (otavio_raposo@iscte-iul.pt) - Instituto Universitário de Lisboa (ISCTE-IUL), Centro de Investigação e Estudos de Sociologia (CIES-IUL), Portugal.

\section{INTRODUÇÃO}

Este artigo surge de pesquisas desenvolvidas recentemente pelos seus autores, que versam a arte urbana e a sua relação com a cidade contemporânea. De especial relevância é o enfoque conferido à articulação entre a arte urbana e os poderes públicos locais, naquilo que podemos definir como políticas para a arte urbana. De facto, constatamos que em muitas cidades, ao redor do planeta, a arte urbana surge como um elemento inevitável na paisagem, tendo-se banalizado. Importa, pois, entender como ocorreu esse processo que transformou algo que era originalmente desprezado, num elemento que é atualmente não apenas valorizado, mas se enquadra cada vez mais na categoria de arte pública. É mesmo de um processo de enobrecimento que estamos a falar, envolvendo um conjunto de atores sociais, com posições e práticas distintas.

Os poderes públicos desempenham, a este respeito, um papel relevante, na medida em que, quer do ponto de vista legislativo, quer do ponto de vista operativo, regulam a forma como as cidades se desenvolvem, de acordo com certos modelos e objetivos. Deste modo, a expansão da arte urbana nas cidades não se dá sem que exista uma certa abordagem por parte dos municípios a este tipo de expressões. Estas abordagens podem ser mais ou menos definidas e estratégicas ou ser fruto de respostas ocasionais. Também é um facto que podem ser de ordem cíclica, obedecendo à rotatividade democrática dos cargos públicos. No entanto, apesar da possível diversidade de abordagens, algo parece certo: nas últimas duas décadas vem-se trilhando um caminho que aponta para um certo consenso relativamente ao papel e à importância da arte urbana, que passa por processos claros de legitimação e institucionalização.

Neste artigo pretendemos, precisamente, debater estas questões a partir de pesquisas realizadas em ambientes geográficos distintos. Referimo-nos aos contextos de Lisboa e Loures, em Portugal, e de Porto Alegre, no Brasil, incidindo sobre alguns projetos emblemáticos realizados nestes territórios. As pesquisas, de índole qualitativa e etnográfica, foram desenvolvidas nos últimos anos, correspondendo a empreendimentos de diferente natureza que, em certos momentos, 
convergiram. ${ }^{1}$ Neste âmbito, para além da observação no terreno, foram realizadas diversas entrevistas aprofundadas a representantes dos poderes locais, a artistas, a moradores e agentes locais dos bairros abrangidos por estes projetos. ${ }^{2} \mathrm{O}$ artigo surge das reflexões desenvolvidas pelos autores conjuntamente, a partir dos dados recolhidos nos seus trabalhos de pesquisa. As conclusões que tiramos confirmam esta tendência para entender a arte urbana do ponto de vista estratégico e utilitário, considerada como um instrumento relevante para a produção da paisagem urbana, que pode ter fortes implicações territoriais, sociais e económicas.

\section{ARTE URBANA, PROCESSOS DE ARTIFICAÇÃO E INSTITUCIONALIZAÇÃO}

O termo arte urbana, nalguns casos street art, entrou já no discurso comum, sendo habitual partirmos de um pressuposto genérico de que todos o entendemos, pelo que não se justifica maior detalhe na sua definição. Aquilo que parece estar na base deste consenso diz respeito a uma avaliação de índole estética. Se é bonito, agradável e decorativo, deve ser arte urbana. Ou seja, alcançado o estatuto de "Arte", as obras incluídas neste movimento estético adquirem, automaticamente, reconhecimento público e social. Não podemos esquecer que a Arte é um termo com efeitos normativos e reguladores, definindo balizas de ordem estética e conceptual sobre as quais se funda uma hierarquização simbólica dos bens (Alexander 2003; Inglis 2005).

Incluir uma obra na categoria de "arte urbana" implica, então, uma valorização simbólica da mesma. Isto envolve um juízo de gosto que é realizado de acordo com certos critérios que endereçam para a técnica, o estilo e a linguagem formal de uma peça pictórica. Aquilo que acontece é que estes critérios são

1 Referimo-nos aos seguintes projetos: TransUrbArts (2017-2020), coordenado por Ricardo Campos, financiado pela Fundação para a Ciência e a Tecnologia (IF/01592/2015) e desenvolvido no CICSNova; "As Políticas da Criatividade: Graffiti, Muralismo e Desenvolvimento Urbano em Porto Alegre e Lisboa" financiado pelo Conselho Nacional de Desenvolvimento Científico e Tecnológico (CNPq 2017-2021) e desenvolvido por José Luis Abalos Júnior; "Novos Tons de Cidadania: Participação Sociocultural dos Jovens nos Subúrbios de Lisboa”, de Otávio Raposo (2014-2018), financiado pela Fundação para a Ciência e a Tecnologia (FCT) e desenvolvido no quadro institucional do ISCTE - Instituto Universitário de Lisboa e do Centro de Investigação e Estudos de Sociologia (CIES-IUL).

2 As diferentes pesquisas realizadas pelos autores resultaram em formulações metodológicas distintas e abordagens ao terreno também elas variadas, embora partilhem uma matriz qualitativa e etnográfica. No projecto TransUrbArts foram realizadas cerca de 35 entrevistas a diferentes atores sociais localizados na área metropolitana de Lisboa (AML) (artistas, responsáveis autárquicos, galeristas, curadores, guias turísticos, etc.). Já em Porto Alegre a pesquisa teve referencial teórico metodológico a etnografia de rua (Eckert e Rocha 2013), assim como produção de 18 entrevistas semidiretivas realizadas junto a artistas urbanos e mediadores culturais que participam de um circuito de financiamento de projetos ligados ao muralismo urbano. Por sua vez, a pesquisa sobre a arte urbana na Quinta do Mocho ocorreu nos anos de 2016 a 2018, num mergulho etnográfico em que foram feitas mais de 50 idas a campo e realizadas 15 entrevistas em profundidade, além de filmagens, fotografias e registos no diário de campo. 
simultaneamente inclusores e excludentes. Servem para deslegitimar e excluir certas linguagens que não se inscrevem neste domínio e, como tal, são consideradas "não-arte", sendo na maioria dos casos manifestações de poluição visual e vandalismo. Nesta categoria entram os casos da pixação e de certas formas de graffiti não autorizado, como tem sido destacado pela literatura (Campos 2010; Castleman 1982; Ferrell 1996; Figueroa Saavedra 2006; Macdonald 2001; Pereira 2016, 2012; Ross, 2016a).

Esta distinção, apesar de parecer evidente para a maioria das pessoas, esconde uma relação mais complexa entre estas díspares linguagens visuais urbanas. Na verdade, aquilo que agora glorificamos como sendo arte urbana não apenas descende, como mantém, por vezes, relações de apertada intimidade com as linguagens malditas do pixo ou do graffiti. Podemos certamente afirmar que aquilo que denominamos arte urbana é o corolário de um processo longo de desenvolvimento de uma série de expressões visuais de natureza informal presentes no espaço público.

Em diferentes culturas, regiões e épocas históricas, encontramos distintas formas de utilizar os muros e as paredes com estes propósitos. Assim, podemos invocar os graffiti de Pompeia ou os de Maio de 68, os murais revolucionários soviéticos, chineses, cubanos ou portugueses, o graffti urbano nova-iorquino da década de 70, o pixo de São Paulo, a street art de Banksy ou dos Gémeos. A arte urbana provém de um conjunto de movimentos historicamente mais recentes, ${ }^{3}$ principalmente do graffiti norte-americano da década de 70 que, entretanto, se tornou hegemónico. Esta expressão de origem norte-americana, associada ao movimento hip-hop, rapidamente se expandiu e globalizou, sendo atualmente uma expressão planetária. A pintura a aerossol domina grande parte da arte urbana produzida nos dias de hoje, apesar da crescente multiplicação de técnicas e linguagens expressivas que temos vindo a testemunhar. Esta ligação entre o graffiti e a arte urbana está bem patente na biografia de alguns dos nomes mais relevantes deste movimento artístico que se iniciaram no graffiti ou mantêm uma ligação efetiva com este campo. ${ }^{4}$ Aquilo que encontramos hoje, então, é um novo "mundo da arte" (Bengtsen 2014; Campos e Sequeira 2018), que resulta de um processo social de "artificação" (Shapiro 2012, 2019), através do qual algo que era considerado não-arte, se converte numa fórmula artística legítima. Este processo decorre da ação de diversos atores sociais, como sejam os media, a academia, o mundo da arte ou os poderes públicos (Austin 2010; Waclawek 2011; Campos e Sequeira 2018, 2019). Concomitantemente, registamos também uma gradual institucionalização destas práticas e expressões, que passam pela sua entrada nas galerias e

3 Movimentos de inspiração DIY, ativistas e outras culturas urbanas juvenis.

4 No caso português nomes como Vhils, Mais Menos ou Bordalo II e, no caso brasileiro, nomes como Gémeos, Nunca ou Kobra, são bem reveladores desta forte conexão. 
museus (Bengtsen 2014; Wells 2016), mas também por uma maior regulação destas práticas no espaço urbano (Schacter 2014; Carmo, Matos e Pereira 2019; Pussetti e Barros 2019).

Assim, podemos entender este termo de acordo com o que é avançado por Campos e Sequeira (2018: 80):

“[...] arte urbana é um conceito que serve para caracterizar um movimento artístico reconhecido enquanto tal, surgido num contexto histórico específico. A arte urbana incorpora certas vertentes do graffiti artístico e da street art, representando o corolário do processo de institucionalização e mercantilização destas práticas, devendo ser compreendida neste âmbito. Como tal, entendemos aqui arte urbana, enquanto campo tendencialmente legitimado e sancionado por um conjunto de instâncias sociais."

A arte urbana passou a ser considerada uma categoria integrada, enquadrada num nicho entre a arte contemporânea e a arte pública. Todavia, o facto de esta ter a cidade e o espaço público urbano como o território principal tem vastas implicações. Ou seja, importa falar não apenas do impacto que a arte urbana tem em termos artísticos, no mercado da arte e no usufruto dos bens estéticos, mas também nos impactos paisagísticos, sociais e económicos que pode ter na cidade.

Quando se fala sobre o papel da arte urbana na cidade, aquilo que geralmente é tido em conta é uma visão otimista e benevolente destas práticas, que destaca o teor democratizante e vivificante das mesmas. Ou seja, tornou-se algo consensual a ideia segundo a qual a arte urbana é, de uma forma genérica, benéfica para as cidades (Austin 2010; Miguel-Molina et al. 2013; Mokras-Grabowska 2014; Grondeau e Pondaven 2018). O sucesso que a arte urbana tem alcançado nos últimos anos tem de ser interpretado à luz de um paradigma de planeamento urbano em que as artes e a cultura desempenham um papel cada vez mais saliente. O setor artístico-cultural tem sido considerado crescentemente um capital relevante para a promoção da imagem das cidades e para o seu desenvolvimento. Como defendem Guinard e Margier (2018), a arte assumiu-se como nova norma do planeamento urbano.

Começam, porém, a surgir com alguma insistência perspetivas mais críticas que desvelam outras facetas deste fenómeno (Schacter 2014; Mould 2015; Mcauliffe 2012; Brighenti 2016; Evans 2016; Raposo 2019; Pavoni 2019). As abordagens críticas detalham o papel que a arte urbana tem desempenhado ao serviço de um modelo de desenvolvimento da cidade de matriz neoliberal. Salienta-se a instrumentalização da arte urbana no âmbito de um paradigma, que entretanto se tornou dominante, que tende a entender a cultura e a arte como mais-valias para a dinamização económica das cidades, num mundo globalmente mais competitivo. Essa situação não é alheia a uma retórica que 
assenta na ideia de cidade criativa enquanto modelo de desenvolvimento urbano, como alertam alguns autores (Schacter 2014; Mould 2015; Andron 2018)..$^{5}$

A reconfiguração simbólica das expressões de rua permitiu que estas se convertessem em instrumentos de valorização simbólica e económica do território, como têm demonstrado diversas pesquisas (Mcauliffe 2012; Brighenti 2016; Evans 2016; Pavoni 2019; Castellano e Raposo 2020). Um dos autores mais críticos relativamente a esta situação é Rafael Schacter (2014). Para descrever o que está a acontecer ele emprega o termo de artwashing, salientando o processo de domesticação e de neutralização da componente transgressora originalmente presente no graffiti e na street art. Esta é desprovida do seu caráter insurgente mantendo, porém, uma aura de irreverência e uma estética da margem que é bem-vinda no contexto de uma cidade criativa que vive da renovação das ofertas culturais e artísticas.

Logo, a construção da paisagem tem por base critérios de ordem estética e normativa que delimitam aquilo que é incluído, ou excluído, desta categoria de arte urbana e, portanto, merece ser promovido, ou não. Daí que, frequentemente, as estratégias de visibilização da arte urbana sejam acompanhadas por ações invisibilizadoras de realidades sociais e expressões indesejadas não conformes a um gosto normativo e a um projeto de place marketing que visa a valorização económica e simbólica de um dado território (Schacter 2014). As expressões artísticas indesejadas estão, desde sempre, associadas a uma ideia de poluição simbólica, que quando vinculada a um determinado território pode acarretar desvantagens económicas na competição por investimento urbano. Daí que grande parte do historial do graffiti e do pixo reflita precisamente medidas empregues pelos poderes locais e autoridades policiais no sentido da sua contenção e irradicação (Campos 2010; Ferrell 1996; Ross 2016b; Pereira 2016).

No contexto que agora tratamos, Mcauliffe (2012) aplica o termo "geografias morais" que nos parece especialmente acertado. De acordo com o autor há uma avaliação social sobre as expressões de rua, que determina que algumas sejam entendidas como "deslocadas" (out of place). ${ }^{6}$ Como referem Guinard e Margier (2018: 19), inspirando-se nos casos de Montreal e Joanesburgo:

"While promoting street art, public authorities ultimately only support an 'official' and consensual art form whose visibility underpins the creation

5 A ideia de cidade criativa tem sido desenvolvida essencialmente a partir da leitura da obra de Richard Florida (2011), que defendeu a importância da chamada "classe criativa" para o desenvolvimento económico das cidades. O conceito de cidade criativa tem sido desenvolvido por diversos autores, sendo de destacar a este respeito o trabalho de Landry (2000).

6 A ideia do graffiti enquanto expressão deslocada (out of place) foi inicialmente desenvolvida pelo geógrafo Tim Cresswell (1992). 
of an international and attractive image. All artwork that opposes this desired atmosphere is banished while potentially subversive art is highly controlled. The analysis of art in public spaces is thus enlightening to understand the evolution of what are both public spaces and art".

\section{POLÍTICAS PÚBLICAS DE ARTE URBANA: TRÊS ESTUDOS DE CASO}

Os poderes locais abordam de forma muito distinta o fenómeno do graffiti e da arte urbana, como a literatura tem vindo a dar conta (Ferro 2016; Campos, 2021 ; Campos e Câmara 2019; Ross 2016a, 2016b). De um modo geral, atualmente parece ser consensual a ideia de que a arte urbana, independentemente da definição que lhe possamos atribuir, é um recurso importante de valorização territorial. De igual modo, também é relativamente unânime a perspetiva de que um conjunto de expressões ilegais, como tagging, bombing, ${ }^{7}$ pixação, ${ }^{8}$ etc., são indesejáveis. Como tal, as primeiras são geralmente toleradas ou incentivadas, enquanto as segundas são perseguidas e anuladas. Apesar desta tendência genérica, o facto é que existe uma gama muito variada de estratégias de gestão deste fenómeno. Desde logo podemos distinguir duas situações. Por um lado, aquelas em que os poderes públicos locais prosseguem uma política definida, consistente e escrutinada relativamente a esta questão. Esta resulta de uma ponderação e revela consistência ao longo do tempo, permitindo avaliações retrospetivas. Por outro lado, há claramente situações em que não existe um plano definido e em que as respostas são mais intermitentes, casuais e oscilantes, marcadas por alguma falta de visão estratégica. ${ }^{9}$ Se é um facto que as últimas situações são as mais comuns, o sucesso de alguns programas, como sejam os das Câmaras Municipais de Lisboa e de Loures, têm sido uma fonte de inspiração para que outras autarquias desenvolvam estratégias mais coerentes relativamente a esta matéria.

Neste artigo trazemos três exemplos que, em certa medida, se podem considerar casos emblemáticos da forma como os poderes locais entendem a arte urbana e as funções que esta pode desempenhar no desenvolvimento territorial.

7 Forma de graffiti ilegal que consiste na inscrição de assinaturas estilizadas de dimensão variada na cidade.

8 Termo brasileiro que se assemelha ao bombing.

9 Referimo-nos neste caso, principalmente, ao recurso, cada vez mais recorrente por parte dos municípios, aos festivais de arte urbana, que acontecem pontual ou regularmente. Estes visam criar momentos de visibilidade mediática momentânea e parecem obedecer a uma lógica decorativista, de embelezamento do espaço público urbano. Um inventário recente (2017-19) realizado no âmbito do projeto TransUrbArts, revela que existem em Portugal cerca de 42 festivais, sendo 14 deles realizados na AML. A título de exemplo, podemos referir os festivais Wool (Covilhã), Muro (Lisboa), Loures Arte Pública, Muraliza (Cascais), ESTAU-Estarreja Arte Urbana, Festival Iminente (Oeiras e Lisboa), etc. 


\section{A GAU E O FESTIVAL MURO NA CIDADE DE LISBOA}

É impossível falar de políticas públicas municipais relativamente à arte urbana em Lisboa sem falarmos do caso da Galeria de Arte Urbana (GAU). ${ }^{10}$ A GAU é uma estrutura criada pela Câmara Municipal de Lisboa em 2008 que, de acordo com informação disponível no seu website, "tem como principal missão a promoção do graffiti e da street art em Lisboa, dentro de um quadro autorizado e segundo uma ótica de respeito pelos valores patrimoniais e paisagísticos, em oposição aos atos ilegais de vandalismo que agridem a Cidade". ${ }^{11}$ A sua estratégia é baseada, desde as suas origens, num diálogo com a comunidade de graffiti writers e street artists, promovendo uma cultura de aproximação. Outros princípios que nortearam esta estratégia assentam na valorização da paisagem e distribuição geográfica das obras (no centro e periferia da cidade), numa lógica de acesso à arte de índole mais democrática e participativa. Deste modo, ao longo de mais de uma década dinamizou iniciativas diversas que alteraram por completo a paisagem visual da cidade. A GAU foi fundamental na criação de redutos autorizados para a prática do graffiti, mas também para o florescimento de uma cultura do muralismo de grandes dimensões, envolvendo fachadas, empenas e muros. Os impactos desta política têm sido salientados (Grondeau e Pondaven 2018; Campos e Sequeira 2019; Campos e Câmara 2019) e resultaram numa maior visibilidade internacional da cidade, que passou a figurar em diversos media e na literatura especializada, como um dos locais onde se produz melhor arte urbana.

Um dos seus projetos mais recentes e que mais impacto tem tido é o do festival Muro, iniciado em 2016 e que conta com três edições. Este festival tem sido realizado em diferentes bairros da cidade que podemos caracterizar como sendo algo periféricos do ponto de vista territorial e que possuem características sociais particulares. ${ }^{12}$ A primeira edição do festival ocorreu no bairro Padre Cruz, a segunda edição no bairro de Marvila e a última edição no Lumiar. Os dois primeiros correspondem aos denominados "bairros sociais", bairros municipais de rendas controladas, sobre os quais se fabricou todo um imaginário social que remete para a natureza problemática do território e dos seus habitantes. No caso do Lumiar, apesar de encontrarmos uma situação diferente, o facto é que as intervenções ocorreram basicamente num perímetro com as mesmas características.

10 Para uma análise mais profunda e detalhada do projeto e das iniciativas desenvolvidas pela GAU, ver Campos e Câmara (2019).

l 1 Disponível em < http://gau.cm-lisboa.pt/gau.html > (última consulta em outubro de 2021).

12 Esta iniciativa não foi a primeira desencadeada pela GAU em territórios periféricos, utilizando o graffiti e a arte urbana, como revela a sua participação em 2011 num projeto de intervenção comunitária em Marvila (Ferro et al. 2014). 
Daí que a escolha destes territórios não tenha sido realizada ao acaso. Há toda uma intenção que subjaz à seleção destes bairros que parte, desde logo, do pressuposto de que estes são territórios com diversas carências e problemas. Deste modo, a realização de eventos desta natureza tem por objetivo uma ação sobre a paisagem visual do bairro que visa uma requalificação da mesma. Segundo a coordenação da GAU, a partir de 2014 percebeu-se que a pintura em grande escala, em empenas de edifícios, tinha um impacto substancial na cidade. Essa repercussão não seria apenas de ordem estética, mas estaria relacionada com a melhoria do espaço público e da relação das comunidades com o território:

"Por um lado, percebemos que a pintura faz com que as pessoas se apropriem do espaço público e sintam orgulho dele. É uma constatação, que as pessoas - as que vivem lá e o público em geral - passam a olhar para esse território de outra forma e com outra responsabilidade. Ou seja, o território tem mais visibilidade, mais pessoas a entrar e, como tal, outro tratamento. E isso nós percebemos, porque sempre que desenvolvemos uma atividade, esta vai recuperar ou ganhar aquilo que é o espaço público. As pessoas veem como um espaço de obras de arte e passam a ter outra relação com ele" [entrevista realizada a Hugo Cardoso, integrante da equipe da Galeria de Arte Urbana, fevereiro de 2019].

O festival Muro arranca, assim, em 2016 de forma promissora, com a realização de diversos eventos e a produção de cerca de 30 obras, executadas por cerca de meia centena de artistas nacionais e estrangeiros. Numa entrevista ao jornal Sol nesse ano, uma responsável da GAU indica claramente quais os pressupostos subjacentes a este modelo de intervenção. De acordo com essa entrevista, interessa à CML "trabalhar novas centralidades através da arte urbana, enriquecer um território que normalmente não acolhe este tipo de atividades", acrescentando ainda que a arte urbana pode servir para a "revitalização de zonas deprimidas e de inclusão social", sendo "um impulso para melhorar a vida dos moradores". Por último, expressa-se o desejo de que "o festival trouxesse visitantes ao bairro e que isso o ajudasse a desenvolver-se”. Este programa foi legitimado ao mais alto nível com um encerramento do festival que contou com a presença do presidente da Câmara de Lisboa, Fernando Medina, e com o presidente da República, Marcelo Rebelo de Sousa.

Neste texto trazemos a experiência do segundo festival Muro, ocorrido no bairro de Marvila em 2017. Contrariamente ao bairro Padre Cruz, local da primeira edição do festival, Marvila é um bairro misto com edifícios públicos e privados. Antigamente nesta região localizava-se o "bairro Chinês", constituído basicamente por barracas. Nos anos 90, através das políticas do PER - 
Programa Especial de Realojamento, ${ }^{13}$ são construídos grandes edifícios para abrigar a população carente da região. Estamos a falar de uma região com um histórico de industrialização que abrigou muitas fábricas, caracterizando-se por ser um bairro de operários. Com a crise da indústria a região viu desaparecer muitos postos de trabalho. ${ }^{14}$

O festival Muro neste bairro não pode ser entendido sem pensarmos em três fatores decisivos para a sua implementação em maio de 2017. O primeiro diz respeito à instalação de uma biblioteca municipal. Segundo o coordenador da biblioteca, ela foi pensada no âmbito da política de alargamento de oferta destes equipamentos e "teve o seu projeto muito debatido entre moradores, que tinham dúvidas sobre o sucesso do futuro equipamento cultural". ${ }^{15}$ O entorno da biblioteca é marcado pela presença de grandes prédios que foram alvo de intervenções murais durante o festival. Produtos de uma política de descentralização cultural da autarquia, tanto a biblioteca de Marvila quanto o festival Muro fazem parte de projetos municipais que, segundo o coordenador da biblioteca, não visam tirar as pessoas da pobreza, mas "criar públicos que possam fruir de programação artística". ${ }^{16}$

Outro elemento importante a considerar é uma aposta nesta zona da cidade de Lisboa que aponta para o desenvolvimento da economia criativa na região do Beato, contígua de Marvila. Um dos exemplos mais claros é o do fenómeno de criação de novos espaços artísticos e culturais na região, maioritariamente fomentados pela iniciativa privada, ${ }^{17}$ que são acompanhados por outras atividades ligadas à economia da noite e do lazer. A migração, definitiva e pendular, de jovens emprendedores criativos, para Marvila é uma realidade atual, assim como a valorização imobiliária. Não por acaso, o preço das casas em Marvila disparou quase $80 \%$ em 2018 em relação ao ano anterior, naquele que foi o maior aumento do preço por metro quadrado entre as freguesias de Lisboa. ${ }^{18}$

13 No portal da habitação, os objetivos do PER são descritos da seguinte forma: "O Programa de Realojamento visa proporcionar aos municípios condições para proceder à erradicação das barracas existentes e ao, consequente, realojamento dos seus ocupantes em habitações de custos controlados". Disponível em < https://www.portaldahabitacao.pt/pt/portal/programas_de_financiamento/per.html > (última consulta em outubro de 2021).

14 Para mais referências ver Projeto Rock desenvolvido por pesquisadores de várias áreas sobre as regiões de Beato e Marvila: < https://lisboa.rockproject.eu/ > (última consulta em outubro de 2021).

15 Narrativa trazida por Paulo José Silva, coordenador da biblioteca de Marvila, em maio de 2019, em conversa informal com os pesquisadores.

16 Reportagem do jornal Público, de 8 de novembro de 2018; "Já sabemos para que serve uma biblioteca em Marvila”. Disponível em < https://www.publico.pt/2018/1 1/09/local/noticia/ja-sabemos-servebiblioteca-marvila-1850368 > (última consulta em outubro de 2021).

17 Um bom exemplo neste sentido é a Underdogs Gallery. Inaugurada em 2013, é um espaço de exposição que trabalha com alguns dos mais renomados artistas contemporâneos de inspiração urbana de todo o mundo. Ver mais em < https://www.under-dogs.net/ > (última consulta em outubro de 2021). 18 Para mais informações, ver < https://www.publico.pt/2019/05/07/economia/noticia/precos-freguesia-marvila-dispararam-quase-80-1871749 > (última consulta em outubro de 2021). 
Tendo como temática "O passado e o presente: Lisboa capital ibero-americana da cultura 2017", o segundo festival Muro pretendeu proporcionar um momento de encontro e partilha entre artistas de arte urbana provenientes de países ibero-americanos. A questão que se colocava aqui, e que acompanhou os debates da organização do festival, era em que medida essa temática se poderia articular com a cultura local. Ao contrário da primeira edição do festival, na qual não havia uma delimitação neste sentido, agora o festival tinha um conceito no qual os artistas baseavam a sua produção visual em grande escala. No que se refere à produção do evento houve a criação de 15

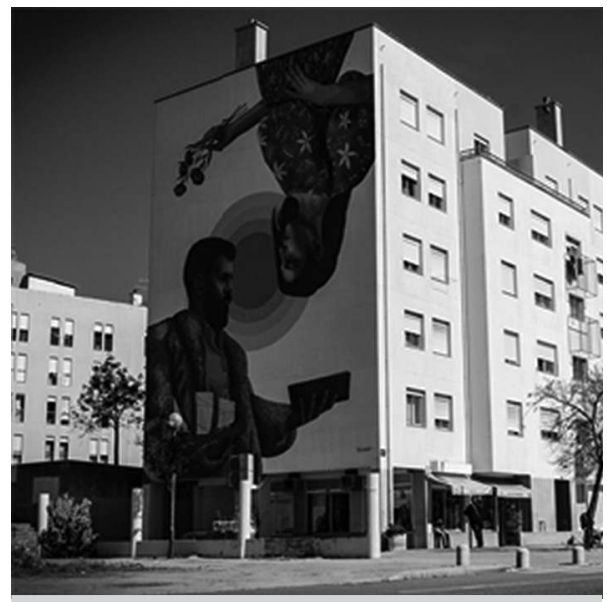

Figura 1 - Obra "The meeting between the past and present" do coletivo uruguaio Licuado. Empena pintada no festival Muro de Marvila. Fonte: Fotografia de José Luís Abalos Júnior. obras em grande escala em empenas e noutras superfícies como muros e instalações sanitárias públicas. A curadoria baseou-se em três dimensões: artistas criadores nacionais, artistas provenientes de países ibero-americanos e artistas vencedores dos concursos lançados para realização das intervenções artísticas.

A participação dos habitantes do bairro nestes processos é complexa e depende de um conjunto de fatores, facto reconhecido pela GAU:

"Nós discutimos muitas vezes se devemos ir ou não ao encontro das expectativas das pessoas. Mas é sempre uma conversa muito dura, porque não conseguimos. Se pusermos dez pessoas e perguntarmos o que querem ver pintado na parede, cada uma vai ter uma expectativa diferente da outra. Nós entendemos que esses grandes projetos, ligados ao desenvolvimento territorial, têm grandes impactos de coesão social no qual há um nível de participação e cuidado maior com o espaço público" [entrevista realizada a Hugo Cardoso, integrante da equipe da Galeria de Arte Urbana, fevereiro de 2019].

Todavia, uma das formas de incluir a comunidade nos projetos é através da participação de atores locais. Uma das medidas salientadas pela GAU é a identificação de, e convite a, artistas locais, nascidos nas comunidades onde os eventos decorrem. ${ }^{19}$ No que se refere à avaliação de impactos, a própria GAU 
reconhece que "não há uma avaliação de impactos formal e sistematizada", ${ }^{20}$ porém há o desejo de que isto ocorra futuramente. Segundo os gestores do festival Muro em Marvila, que inclui a Galeria de Arte Urbana e a biblioteca, tem-se uma avaliação positiva do festival Muro no bairro, mesmo não havendo uma política de análise de impactos devidamente sistematizada. A perceção destes gestores é a mesma de LS, artista local que participou ativamente das atividades durante o festival. Para LS,

"Eu como cidadão de Marvila achei muito giro... Festival Muro pra mim abriu portas. As pessoas começaram a usar mais as ruas, mas não creio que o impacto seja tão grande. Muitas vezes é só estética. Deviam organizar mais visitas guiadas, restaurar obras que já estão deterioradas e fazer um projeto só com novos talentos que estão a surgir. Em Portugal parece que são sempre os mesmos a pintar empenas. Ou é gente de fora" [entrevista realizada ao artista urbano LS, maio de 2019 na biblioteca de Marvila].

DO BAIRRO PARA O MUNDO:

A GALERIA DE ARTE PÚBLICA DA QUINTA DO MOCHO

A Galeria de Arte Pública da Quinta do Mocho (GAP) é um dos projetos de arte urbana de maior visibilidade em Portugal. Reúne mais de 100 murais em grande escala a decorar os prédios do bairro de habitação social, onde vivem cerca de 3000 pessoas. Considerada uma das maiores galerias a céu aberto da Europa, este projeto é dinamizado pela Câmara Municipal de Loures (CML), agrupando no seu portfólio uma ampla diversidade de obras, algumas delas assinadas por renomados artistas portugueses (Odeith, Bordalo II e Vhils) e internacionais (Hopare, Utopia e Vinie).

Foi em 2014 que os seis primeiros murais do bairro foram pintados, ainda no contexto de "O Bairro i o Mundo", um festival em que a arte urbana era desenvolvida conjuntamente com outras expressões artísticas: música, teatro, dança, etc. No ano seguinte este projeto transformou-se na GAP, quando o número de murais cresceu exponencialmente, tornando-se o método privilegiado de intervenção no bairro. ${ }^{21}$ Sobre a importância da GAP, um dos vereadores da autarquia referiu:

"Este trabalho [GAP] só por si já vale muito porque são 51 empenas, mas nós queremos sublinhar muito a mudança que o bairro teve na atitude,

20 Entrevista realizada a Hugo Cardoso, integrante da equipe da Galeria de Arte Urbana, em fevereiro de 2019 .

21 A organização do festival "O Bairro i o Mundo" era da responsabilidade da CML com a Associação de Teatro Ibisco. Com a mudança de gestão da autarquia, este projeto transformou-se na GAP, quando deixou de haver um festival e o seu comando passou a estar sob responsabilidade exclusiva da CML. 
na própria estrutura física, na limpeza que os próprios moradores também exigem e participam. No controlo, no autocontrolo, de quando os rapazes pequenos fazem disparates, em que não se deixa. Foi de facto restituído ao bairro o orgulho que precisamos."

Antes de se transformar num território proeminente de arte urbana, a Quinta do Mocho era fortemente estigmatizada pelos meios de comunicação social. Habitado maioritariamente por populações negras e de origem africana, este bairro era associado a um imaginário de criminalidade, uma área degradada e moralmente "poluída", e os seus jovens moradores eram considerados potenciais delinquentes (Raposo et al. 2019).

Para lidar com essa imagem pública negativa, o anterior executivo camarário alterou o nome do bairro para Urbanização Terraços da Ponte em 2008. Contudo, esta estratégia mostrou-se ineficaz, pois as notícias depreciativas não cessaram e os moradores continuaram a nomeá-lo como Quinta do Mocho, afirmando um sentimento de pertença articulado com a memória do bairro. ${ }^{22}$

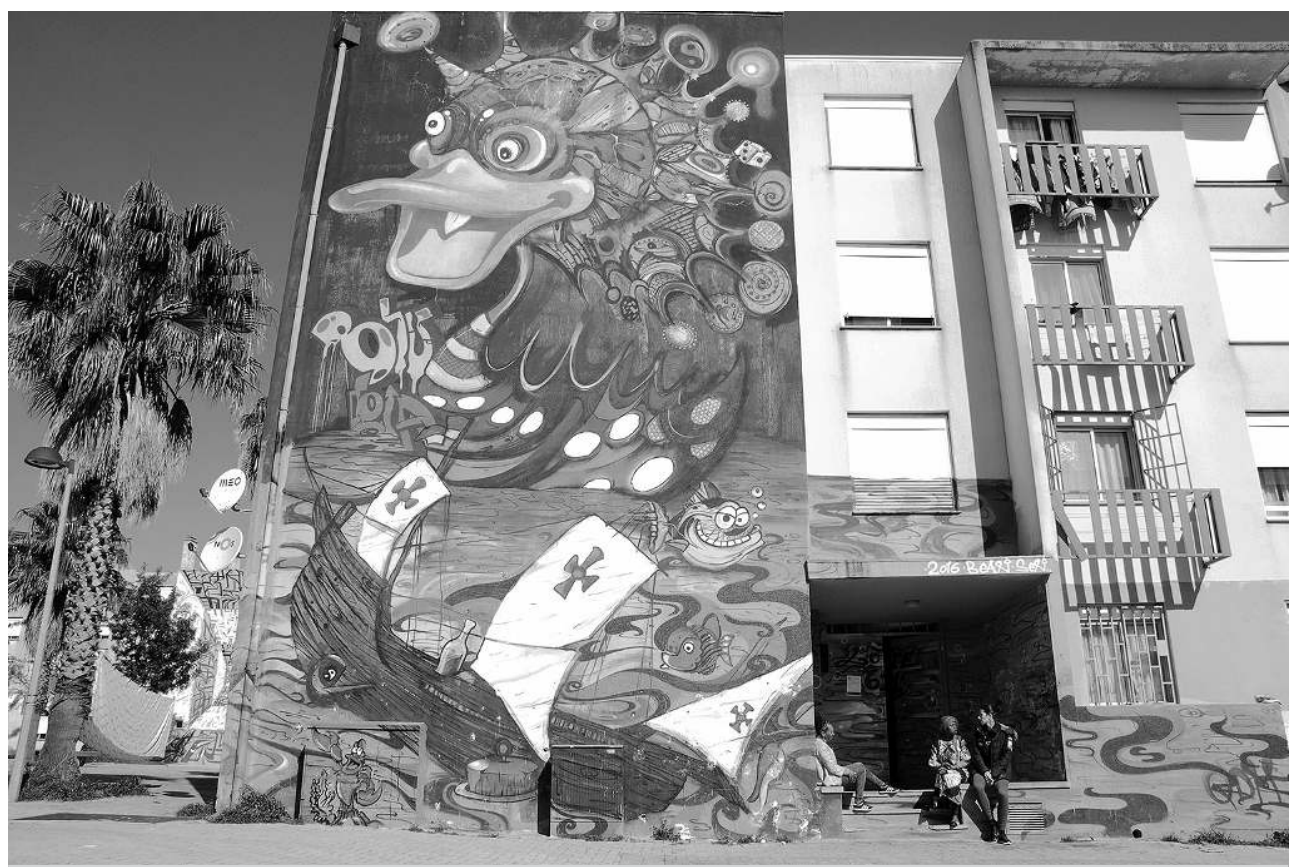

Figura 2 - Mural pintado pelos artistas Bean \& Sen. Fonte: fotografia de Otávio Raposo.

22 Formada por 91 prédios, a Quinta do Mocho foi edificada no final da década de 1990, no âmbito do PER, para abrigar famílias que viviam em condições extremamente precárias, nomeadamente em torres inacabadas sem infraestruturas básicas: água, luz, saneamento. A falência da construtora J. Pimenta levou ao abandono desses edifícios, entretanto ocupados na década de 1980 por imigrantes oriundos da Angola, Guiné-Bissau e outros países africanos de língua oficial portuguesa (PALOP). 
A preocupação em combater o estigma territorial também foi um dos objetivos da GAP, que encontrou na arte urbana um poderoso aliado. A valorização simbólica da Quinta do Mocho configura um êxito dessa política pública, pois o bairro deixou de ser identificado como sinónimo de violência pelos discursos mediáticos. ${ }^{23}$ Reconvertida em território de arte e cultura, a Quinta do Mocho foi tema de inúmeras reportagens jornalísticas por conta da sua paisagem visual, tornando-se também uma atração turística para os apreciadores de arte urbana e aqueles que buscam experiências autênticas em territórios multiculturais (Loukaitou-Sideris e Soureli 2012; Raposo 2019).

O sucesso da GAP levou a autarquia a expandir a arte urbana para todo o concelho, criando o festival Loures Arte Pública (LAP) em 2016. Desde então, quase uma centena de artistas de múltiplas nacionalidades passou a vir a Loures todos os anos para fazer obras de grandes dimensões em muros, prédios habitacionais, autocarros, escolas e outros equipamentos públicos: depósitos de água, caixas de eletricidade, etc. Durante a LAP, a GAP não só continuou a ser alvo de intervenções artísticas, como também se converteu na principal atração desse festival, assegurando uma projeção mediática que serve de mais-valia para a atual governação. ${ }^{24}$

A aposta na requalificação da Quinta do Mocho por via da arte urbana foi manifestada por políticos e funcionários autárquicos em inúmeras visitas guiadas ao bairro, uma retórica que se complementa com a idealização da GAP como instrumento para a integração social. Esta perspetiva foi abordada por Bernardino Soares, presidente do município, num debate televisivo entre os candidatos que concorriam a essa autarquia:

"O que nós fizemos na Quinta do Mocho foi de facto um programa de grande sucesso que visou, em primeiro lugar, a integração social, e depois ultrapassou muito isso, porque hoje é uma mais-valia cultural de grande nível europeu e mundial. Nós ali temos visitas todas as semanas, agências de viagens trazem turistas dos cruzeiros para irem visitar a Quinta do Mocho. E o bairro transformou-se" [TVi24, programa A Caminho das Autárquicas Loures, 19/07/2017].

Tema "quente" das eleições para a autarquia em 2017, a Quinta do Mocho encarna o novo papel que arte e cultura estão a desempenhar enquanto motor do desenvolvimento urbano, numa altura em que, como vimos, o modelo de cidade criativa se tornou numa referência incontornável na governança local (Castellano e Raposo 2020).

23 Para um debate mais aprofundado sobre a amplitude da transformação nas representações sobre o bairro veiculada pelos media, ver Raposo (2018).

24 Para mais informações sobra a LAP, ver < https://www.cm-loures.pt/Conteudo.aspx? DisplayId=60 $89>$ (última consulta em outubro de 2021). 
As conexões estimuladas pela vinda de turistas no âmbito da GAP acrescentam valor simbólico ao bairro, ajudando também a (re)modelar a imagem de Loures enquanto cidade moderna e cosmopolita. ${ }^{25}$ Ao atrair "mais visitantes do que a maioria dos museus", ${ }^{26}$ a Quinta do Mocho adquiriu centralidade nesse processo de afirmação de uma marca de cidade, um processo de city branding em que os murais de arte urbana servem como capital criativo tanto para produzir uma imagem de distinção quanto de excelência de governação (Zukin 1995). É neste contexto que a arte urbana se transforma em política pública em Loures, uma commodity valiosa para os poderes públicos intervirem na valorização territorial, no desenvolvimento local, no fomento do turismo ou mesmo nas disputas político-eleitorais.

A visibilidade de que desfruta esse projeto de arte urbana deve-se, em grande parte, aos guias comunitários, responsáveis por trazer turistas à Quinta do Mocho nas visitas que dinamizam. ${ }^{27}$ Habitantes do bairro, estes guias souberam explicar à população os benefícios potenciais que teria com a pintura dos prédios, contribuindo para que a desconfiança inicial fosse ultrapassada. ${ }^{28}$ Os efeitos da inversão do estigma territorial nos moradores foi o aspeto mais aplaudido da GAP por um dos guias comunitários:

"A melhor coisa que aconteceu nesse projeto foi a população voltar a se sentir valorizada. Esse foi o maior troféu que essa galeria poderia ter dado, foi a melhor coisa que essa galeria deu ao bairro. [...] A notícia que para mim foi a melhor de todas foi nós, um bairro que era problemático, sermos comparados com um sítio de cultura em que as pessoas vão e querem visitar. E nós, afinal, termos tanto valor como um museu" [entrevista realizada a um dos guias comunitários, abril de 2017].

A GAP também era apresentada pela autarquia como um primeiro passo para trazer investimento público a um bairro marcado por más condições de

25 Não deixa de ser curioso que Loures era uma cidade que promovia a sua identidade saloia antes de se tornar uma "capital" da arte urbana em Portugal.

26 Esta frase foi pronunciada por Bernardino Soares e publicada pelo jornal Público. Disponível em $<$ https://www.publico.pt/2016/05/12/local/noticia/o-bairro-onde-ninguem-queria-entrar-ja-recebe-mais -visitas-do-que-os-museus-1731827 > (última consulta em outubro de 2021).

27 Com pouco mais de uma centena de obras entre as mais de 500 presentes em Loures, a Quinta do Mocho é o único local do concelho onde se realizam visitas guiadas aos murais de arte urbana.

28 Os guias comunitários foram voluntários da CML nos primeiros anos de implementaçãa das visitas guiadas na GAP, quando eles eram incentivados a serem empreendedores através da venda de produtos de merchandising (imãs, bottons, canecas) para os turistas. Contudo, ao tornaram-se prestadores de serviços gratuitos à CML, eles sentiram-se explorados e instrumentalizados pela autarquia. Após muitas pressões, eles passaram a receber uma ajuda de custo da autarquia. Para um aprofundamento sobre o modo como os interesses em torno da GAP foram disputados entre os guias e a autarquia, ver: Raposo (2018 e 2019). 


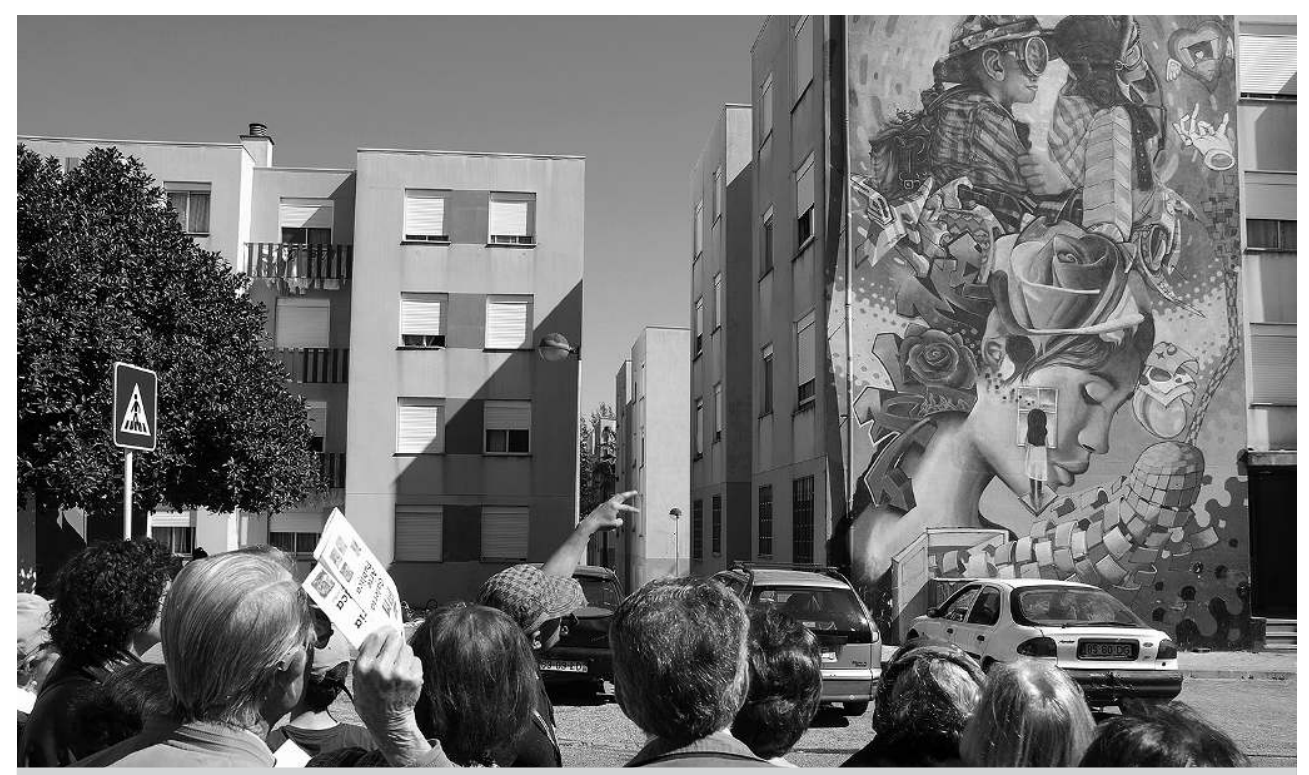

Figura 3 - Visita guiada. Fonte: Fotografia de Otávio Raposo.

habitabilidade. Contudo, a multiplicação de obras artísticas não alterou o regime de urbanidade precária dos seus habitantes, que continuam a conviver com graves problemas de infraestrutura urbana: apartamentos deteriorados e com infiltrações, parques infantis e áreas de lazer degradados, infestação de mosquitos, etc. (Raposo 2019). Apesar de algumas reivindicações dos moradores terem sido atendidas - linhas de autocarro a percorrer o bairro, rampas para deficientes, porta na entrada dos edifícios -, muitos moradores passaram a questionar os reais benefícios da GAP, mostrando insatisfação.

"Eu falo por mim, estou farto de graffiti. Temos imensos graffiti, mas os mosquitos de que falamos na reunião comunitária continuam. É muito mais importante para a minha saúde os mosquitos que os graffitis. Os parques infantis continuam por arranjar [...]. Vão ganhar as eleições novamente com a demagogia de que melhoraram imenso esse bairro, quando não melhoraram coisa nenhuma. Foi uma operação de estética no bairro, dão uma aparência mais bonita para os turistas que vêm cá" [entrevista realizada a um morador da Quinta do Mocho, agosto de 2017].

Mais críticos em relação a esse projeto de arte urbana, os guias comunitários passaram a atuar como mediadores das demandas dos habitantes. Nas visitas guiadas que dinamizam, não escondem as ambivalências de uma política pública que ressignifica a Quinta do Mocho no campo das virtudes, mas incapaz de contrariar o regime de subalternidade em que os moradores estão 
imersos. Neste caso, os murais artísticos embelezariam processos de precarização (Raposo 2019), constituindo-se como uma política pública com uma forte componente de art washing (Schacter 2014), em que a arte é um poderoso instrumento de gestão das desigualdades sociais e apaziguamento dos conflitos urbanos. Reprodutora de uma lógica top-down, a GAP não incorpora os moradores no processo criativo de requalificação estética das suas moradias (Raposo 2018). Não é raro eles descobrirem que os seus prédios serão pintados no próprio dia, tendo pouca margem para influenciar a escolha dos signos exibidos. ${ }^{29}$

O impacto da GAP na valorização simbólica da Quinta do Mocho é incontestável, pois o bairro transformou-se numa referência de arte urbana em Portugal e no mundo. Mas ao não ser acompanhada por políticas efetivas de investimento público nas habitações, a GAP frustrou as expetativas de muitos dos moradores, que passam a concebê-la como um projeto de city marketing (Arantes 2000) descolado dos interesses daqueles que habitam o bairro. Incorporar as demandas dos moradores com vista a tornar a GAP mais democrática talvez seja o maior desafio para assegurar a legitimidade dessa política pública, que não pode ignorar aqueles que, em definitivo, dão vida ao bairro. A assembleia comunitária recentemente organizada pela autarquia para debater a reabilitação urbana da Quinta do Mocho mostra o caminho a seguir, uma forma de resistir às pressões de uma mercadorização da arte urbana pautada por um receituário neoliberal promotor de novas formas de gestão da pobreza e controlo do espaço público.

\section{O ZIS GRAFITE NO QUARTO DISTRITO DE PORTO ALEGRE}

Foquemo-nos, finalmente, na cidade de Porto Alegre, localizada no sul do Brasil. O caso que analisamos pode ser considerado uma experiência menos óbvia quando falamos dos projetos ligados à arte urbana neste país. Isto porque, ao pensarmos a temática no Brasil, as cidades de São Paulo e Rio de Janeiro são referências mais importantes pela sua dimensão e capacidade de financiamento. Dito isto, cabe salientar que foram e são raros os projetos públicos que envolvem o investimento em descentralização urbana, financiamento cultural e desenvolvimento territorial. Nos anos 90, com a administração municipal ligada ao Partido dos Trabalhadores, Porto Alegre ficou conhecida por ser a pioneira do Orçamento Participativo no Brasil. ${ }^{30}$ Neste âmbito desenvolveram-se

29 É da responsabilidade dos artistas a eleição dos temas a serem realizados no âmbito da GAP (e da LAP), o que torna a participação dos moradores dependente da sensibilidade dos writers em incorporá-los no processo criativo.

30 O Orçamento Participativo de Porto Alegre é um modelo de gestão municipal participativa que teve o seu início com o advento do Partido dos Trabalhadores na prefeitura em 1989. É um processo dinâmico, pelo qual a população decide, de forma direta, a aplicação dos recursos em obras e serviços que serão executados pela administração municipal. 
políticas públicas urbanas e culturais importantes para a época, como atividades no Ateliê Livre, ${ }^{31}$ Bienais do Mercosul e os Fóruns Sociais Mundiais.

Após este período, o município passa por transformações político-partidárias, investindo muito pouco nas questões ligadas à cultura, com pequenas exceções que se resumiram à área do teatro e do cinema. É a partir de 2010 que o tema da economia criativa aparece fortemente relacionado com uma região histórica da cidade marcada pelos processos de desindustrialização: o Quarto Distrito. Estamos a falar de um conjunto de bairros que conheceu um apogeu económico do início do século XX até à década de 1980, abrigando grandes complexos industriais. A conjuntura que se segue é de desativação da estrutura económica e sistemático encerramento de indústrias, sobretudo de capital local e familiar, que deixam um significativo património edificado em estado de abandono.

De forma que, após a década de 1980, o bairro foi-se deteriorando, tendo-se tornado um bairro simbolicamente desvalorizado, apresentando um conjunto de problemas de diversa ordem. À margem do centro histórico, o Quarto Distrito de Porto Alegre está localizado em uma região entre bairros populares e de classe média e possui um perfil de moradores heterogéneo. Entre trabalhadores das antigas fábricas, moradores de rua e prostitutas, a região tem uma dinâmica peculiar que se vem alterando nos últimos anos devido ao investimento nas formas alternativas de economia e na chegada de novos moradores, como artistas e académicos.

Com as novas dinâmicas, a partir de 2013, o bairro começou a ser chamado "Distrito Criativo", através de uma agência de design social chamada UrbsNova. A região também é reconhecida como Distrito $\mathrm{C}$ e, segundo artistas e empreendedores da nova ideia do bairro, "o Polo Distrito C não é um projeto cultural, é um projeto de inovação social. O que nos motiva é o impacto económico, social e urbano de um coletivo de artistas e empreendedores sobre um território da cidade". ${ }^{32}$ Administrativamente a prefeitura de Porto Alegre denomina a região como Zona de Inovação Sustentável (Zispoa) e incentiva financeiramente projetos que estejam alinhados com a ideia de indústrias criativas na região.

Em Porto Alegre, a Zona de Inovação Sustentável (ZIS) surgiu como uma sugestão de Marc Weiss, professor da Universidade de Washington, que veio trabalhar no Brasil através do Banco Mundial, inspirado na Sustainable Innovation Zone que se traduz, basicamente, em um mapeamento de áreas com

31 O Atelier Livre é um espaço que a prefeitura de Porto Alegre, através da coordenação de Artes Plásticas e da Secretaria Municipal de Cultura, oferece para o público produzir e pensar artes visuais. Foi muito importante na cena do grafitti na década de 90 por proporcionar cursos de pintura para jovens de classe popular.

32 Narrativa retirada da apresentação do site do Distrito Criativo, em $<$ https://distritocriativo.wordp ress.com/ > (última consulta em outubro de 2021). 
potencial de inovação e sustentabilidade da cidade (Weiss 2018). Geralmente esse levantamento leva em conta regióes descentralizadas, degradadas e marcadas pelo abandono. A ideia é que esse tipo de projeto de intervenção social reforce laços de identidade coletiva nos bairros, fomentando ações conjuntas entre moradores, empreendedores e artistas. Tal facto gerou uma alavancagem de investimentos no bairro, tanto do setor privado, quanto do público.

A articulação entre a chamada economia criativa e as práticas de legalização de intervenções artísticas urbanas, como a do graffiti, ocorreu em 2017 através do projeto denominado "ZIS Grafite", gerado a partir da organização da Virada Sustentável no mesmo ano. O Paralelo Vivo, um conglomerado de "empresas criativas" organizadas em "casas colaborativas", ${ }^{33}$ inscreveu-se para participar no concurso denominado "Boas Ideias de Sustentabilidade", que visava alavancar projetos sustentáveis na cidade. Um dos projetos procurava promover atividades e oficinas de melhoria dos bairros através da arte urbana.

Contando com investimento da iniciativa privada e dinheiro público, através da lei de fomento à cultura, o ZIS Grafite caracteriza-se como um "percurso cultural aberto" (Abalos Júnior e Cabreira 2017). Nesse caminho comtempla-se uma prosa virtual, que seria o roteiro de uma estória contada em seis quadros grafitados, percorrendo uma série de imóveis inventariados pelo património histórico e pontos de referência para os moradores dos bairros Independência e Floresta. Essa estória, então, teria por objetivo provocar uma reflexão sobre os temas de preservação ambiental, da nossa relação com o uso dos espaços públicos da cidade e os resíduos. Segundo a arquiteta curadora do projeto, Clara Freund, este foi pensado numa perspetiva de fomento do turismo no Distrito Criativo:

"Porto Alegre é carente desse tipo de percurso aberto, e além dessa carência, a gente tá trabalhando nessa região do Distrito Criativo e do bairro Floresta, que era um bairro que estava muito marginalizado, principalmente a área da avenida Farrapos. Então, dentro do mapeamento do ZIS mesmo, a gente identificou que ali seria um grande potencial pra criar um percurso turístico, pra aproveitar o distrito criativo, que também é outra rede que acontece naquela região, que é entre os empreendimentos, os hotéis, sorveterias, padarias, enfim, todos empreendimentos que geram algum tipo de circulação e inovação no sentido do valor criativo. Então eles apoiaram a ideia de haver um percurso turístico a partir do graffiti ali [...]" [entrevista realizada a Clara Freund, curadora do projeto ZIS Grafite, abril de 2017.]

A verba do projeto destinou-se maioritariamente ao pagamento aos artistas que foram escolhidos por indicação de Binho Ribeiro, artista urbano de São 
Paulo que tem uma trajetória internacional. Como a "Virada Sustentável" já é um evento clássico na cidade de São Paulo, o grafiteiro paulista foi convidado a pintar na cidade e indicou alguns nomes de grafiteiros porto-alegrenses para pintar consigo. Outra questão interessante é a inovação tecnológica do projeto, através da instalação de placard com QRCode, possibilitando que o visitante, utilizando um dispositivo técnico com Internet, consiga percorrer o roteiro dos murais de forma autónoma.

O projeto ZIS Grafite é um bom exemplo de como a crescente legalização e "artificação" do grafitti passa por questões ligadas à descentralização cultural e ao desenvolvimento territorial. No caso de Porto Alegre, isso está diretamente associado ao incentivo maciço da economia criativa. Este processo de reabilitação de bairros industriais degradados cruza-se com outro que surge de forma algo espontânea. É comum que a comunidade de artistas urbanos de metrópoles que passaram por um processo económico/político de desindustrialização opte por realizar intervenções ilegais em edifícios fabris e industriais abandonados. Esses espaços, geralmente abandonados, degradados e pouco vigiados, são especialmente propensos a esse tipo de prática. Em Porto Alegre o que percebemos é uma estratégia política de reabilitação desses lugares, para que se tornem espaços de acolhimento de novas formas de economia, e isto, em maior ou menor medida, inclui as intervenções artísticas urbanas.

Porém, como relata o grafiteiro Celo Pax, o facto de haver uma prática de institucionalização, legalização e ordenamento da paisagem não exclui a ideia

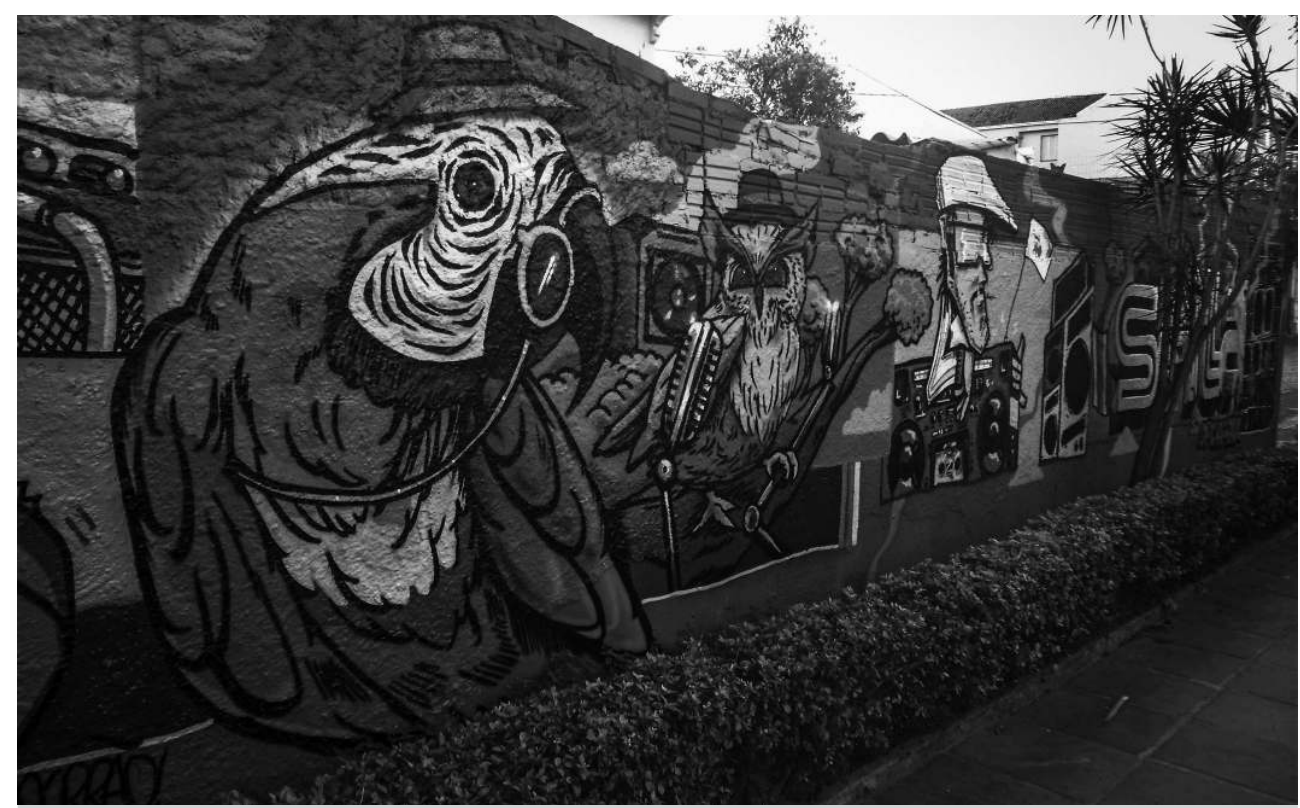

Figura 4 - Intervenções do "ZIS Grafite" no Quarto Distrito de Porto Alegre. Fonte: fotografia de Leonardo Palhano Cabreira. 
primordial de que o Quarto Distrito continue a ser alvo de intervenções não autorizadas:

"Não vejo problemas nestes projetos de legalização e economia criativa, desde que seja feito com respeito. Não me importo nem um pouco. Esses dias um amigo meu que falou 'essa galera do ZIS Grafite nem é do grafittti...', daí eu falei 'mas esses projetos envolvendo grafiteiros a galera do grafite não vai ter bala pra escrever, para aprovar, eu não vou ter, nem outro grafiteiro vai ter'. Tem que ter uns caras que pensem cultura lá pra fazer a frente e depois buscar a gente. Eu não vejo problema nenhum desde que seja feito com cautela, sem passar por cima do grafitti de ninguém." [Entrevista realizada com André Venzon, artistas e gestor cultural, maio de 2017].

André Venzon, artista e curador com prestígio na cidade, vai mais além, colocando críticas ao modo como é empregue o graffiti no âmbito do fomento da economia criativa, da descentralização cultural e do desenvolvimento territorial no Quarto Distrito:

"Estes projetos, públicos e privados, em sua maioria, usam a arte do grafitti pra estampar uma marca e pra não ficar atrás de seus concorrentes. Usam o grafitti como cenário. Eu tenho certeza que esses artistas estão fazendo isso pra sobreviver, como eu faria. Mas para o financiador isso é um trabalho

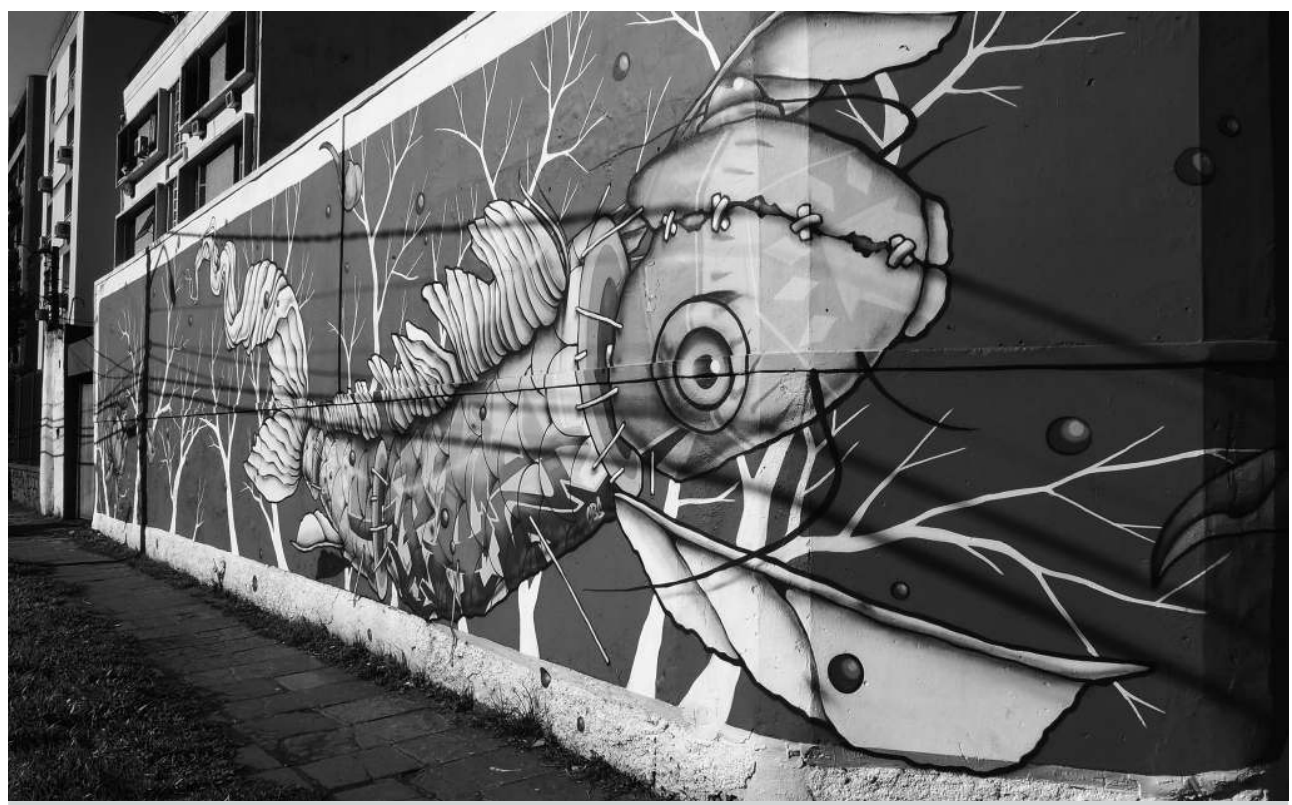

Figura 5 - Intervenções do "ZIS Grafite” no Quarto Distrito de Porto Alegre. Fonte: fotografia de Leonardo Palhano Cabreira. 
aplicado a um produto dessa empresa. Agora, eu quero saber se estes sujeitos que pagam por isso adquiririam alguma obra destes artistas urbanos, se eles foram à exposição deles, então tu te dá conta que não há legitimação no nível que a gente gostaria... É um uso funcionalista." [Entrevista realizada com André Venzon, artistas e gestor cultural, maio de 2017].

De facto, o ZIS Grafite contribuiu para a construção de um certo cenário, para produção de uma paisagem que está em consonância com uma imagem do bairro que se pretende promover. Dois anos após a produção do projeto podemos perceber um aumento não só das visitas turísticas, mas de circulação dos próprios habitantes da cidade que, em muitos casos, desconheciam a região. A proliferação de centros culturais, ateliês de artistas e bares temáticos fez surgir uma cena cultural e uma boémia noturna no bairro. O percurso ZIS Grafite é mais um elemento que contribui para afirmação deste polo cultural.

\section{CONCLUSÃO}

Neste artigo procurámos cruzar diferentes pesquisas e terrenos etnográficos que partilham, em comum, o papel relevante que a arte urbana foi adquirindo enquanto instrumento estratégico para a gestão urbana. Apesar das particularidades locais, as nossas conclusões confirmam aquilo que tem sido destacado por vários autores, segundo os quais a arte e a cultura são hoje entendidas como mais-valias para a valorização do território e da imagem da cidade. No entanto, no caso específico da arte urbana, pelo seu caráter relativamente recente e pelo facto de se ter convertido numa das formas de arte pública mais mediatizadas e mobilizadas por parte dos poderes públicos, há questões novas que emergem.

De acordo com a nossa leitura, a arte urbana tem sido empregue pelas autarquias como um dispositivo que visa a concretização de um conjunto de objetivos interligados. Em primeiro lugar, há um objetivo muito genérico e transversal que remete para a regeneração e dinamização do espaço público urbano, que obedece a um modelo normativo de regulação da paisagem que visa a qualificação e "embelezamento" do território.

Paralelamente, há objetivos que são desenvolvidos a partir de intervenções mais cirúrgicas, dirigidas a territórios entendidos como problemáticos e desqualificados. Os três casos em análise enquadram-se claramente neste perfil, razão pela qual foram aqui tomados como casos de estudo. A Quinta do Mocho e Marvila carregam o estigma largamente atribuído a bairros de habitação social e/ou maioritariamente habitados por imigrantes. O estatuto periférico destes bairros é não apenas geográfico, mas igualmente simbólico. Por seu turno, o Quarto Distrito de Porto Alegre é um território pós-industrial, empobrecido e degradado, marcado por um agregado de situações sociais catalogadas como desviantes (prostituição, tráfico de droga, etc.). 
Nestes casos, não se visa apenas a requalificação da paisagem, mas esta surge nos discursos dos representantes dos poderes públicos como associada a preocupações de cariz social. Não obstante as contradições entre o discurso e as ações efetivas, flagrantes no caso da Quinta do Mocho, a arte urbana é apropriada como instrumento de intervenção social que visa fortalecer os laços dos habitantes com o espaço público e com o bairro, incentivando o espírito comunitário, o orgulho no bairro e a integração social. Estas iniciativas são desenvolvidas ao abrigo de toda uma tradição relacionada com a intervenção comunitária através da arte, ligadas também à ideia de cidadania cultural entre aqueles que são considerados pobres e periféricos (Yúdice 2004; Raposo e Aderaldo 2019). Por último, destaca-se da análise que um dos impactos esperados das iniciativas que envolvem a arte urbana é o de promover o fluxo de visitantes e dinamizar a economia local, alavancando por exemplo o turismo (Jażdżewska 2017; Campos e Sequeira, 2019).

Na verdade, seja a arte urbana o motor principal (caso da Quinta do Mocho) ou apenas mais uma estratégia de intervenção, entre outras (caso do Quarto Distrito), o facto é que esta alteração na paisagem tem acompanhado uma transformação genérica da imagem destes territórios, que contribui para um conjunto de outras metamorfoses. No caso do Quarto Distrito de Porto Alegre, há uma alteração da estrutura económica e do perfil dos habitantes, com maior dinamização da economia cultural e criativa, acompanhado pela economia da noite. No caso da Quinta do Mocho, o grande fluxo de visitantes hoje no bairro é emblemático das reconfigurações da indústria do turismo, um mercado em expansão capaz de transformar antigos territórios marginais - favelas, bairros sociais, inner cities, townships - em opções lúdicas e de consumo cultural. Por seu turno, o turismo também penetrou no bairro intervencionado de Marvila que convive de perto com o desenvolvimento artístico, cultural e económico da área Beato-Marvila. Aliás, quer o Quarto Distrito, quer a área Beato-Marvila afirmam-se como zonas em expansão e em reconfiguração simbólica, revelando-se também apetecíveis para o investimento imobiliário. Estes assumem-se como polos centrais para o fortalecimento de uma economia urbana que assenta na tríade: arte, cultura e noite. A arte urbana funciona como um cenário adequado, estando conotada com a contemporaneidade urbana, a criatividade e a juventude.

Ainda assim, apesar destes impactos sentidos no território, estas intervenções top-down não deixam de criar resistências e dúvidas em muitos residentes. A arte urbana é, por vezes, entendida como uma espécie de panaceia, instrumento de intervenção rápido, barato e eficaz, para regenerar o espaço público urbano (Raposo 2019). Isto porque estas intervenções tendem a não ser acompanhadas de investimentos públicos efetivos na área da arte e cultura direcionadas aos habitantes, tampouco por ações de melhoria efetiva das condições de habitação, do espaço público ou dos transportes. 


\section{BIBLIOGRAFIA}

ABALOS JÚNIOR, José Luís, e Leonardo Palhano CABREIRA, 2017, "Grafite e práticas de legalização: artificação e mediação em expressões artísticas urbanas em Porto Alegre/RS”, PROA: Revista de Antropologia e Arte, 2: 12-24.

ALEXANDER, Victoria, 2003, Sociology of the Arts: Exploring Fine and Popular Forms. Malden e Oxford: Blackwell Publishing.

ANDRON, Sabina, 2018, "Selling streetness as experience: the role of street art tours in branding the creative city", The Sociological Review, 66 (5): 1036-1057.

ARANTES, Otília, 2000, "Uma estratégia fatal: a cultura nas novas gestões urbanas", in Otília Arantes, Carlos Vainer e Ermínia Maricato (orgs.), A Cidade do Pensamento Único: Desmanchando Consensos. Petrópolis: Vozes, 11-73.

AUSTIN, Joe, 2010, "More to see than a canvas in a white cube: for an art in the streets", City, 14 (1): 33-47.

BEnGtSen, Peter, 2014, The Street Art World. Lund: Almendros de Granada Press.

BRIGHENTI, Andrea, 2016, "Graffiti, street art and the divergent synthesis of place valorisation in contemporary urbanism”, in Jeffrey Ian Ross (ed.), Routledge Handbook of Graffiti and Street Art. Londres e Nova Iorque: Routledge, 464-474.

CAMPOS, Ricardo, 2010, Porque Pintamos a Cidade? Uma Abordagem Etnográfica do Graffiti Urbano. Lisboa: Fim de Século.

CAMPOS, Ricardo, 2018, "Arte urbana enquanto património das cidades". Projeto Street Art. Cei. Disponível em < https://streetartcei.com/index.php/investigacao > (consultado em janeiro de 2019).

CAMPOS, Ricardo, 2021, "Poder local, arte urbana e festivalização da cultura", Revista Crítica de Ciências Sociais, 125: 53-76.

CAMPOS, Ricardo, e Ágata SEQUEIRA, 2018, "O mundo da arte urbana emergente: contextos e atores", Todas as Artes, 1 (2): 70-93.

CAMPOS, Ricardo, e Ágata SEQUEIRA, 2019, "Entre VHILS e os Jerónimos: arte urbana de Lisboa enquanto objeto turístico”, Horizontes Antropológicos, 25 (55): 119-151.

CAMPOS, Ricardo, e Silvia CÂMARA, 2019, Arte(s) Urbana(s), Vila Nova de Famalicão: Húmus.

CARMO, André, Filipe MATOS, e Sónia PEREIRA, 2019, "Regeneração urbana através da cultura e das artes: o caso do Barreiro”, Fórum Sociológico, 35: 61-70.

CASTEllanO, Carlos Garrido, e Otávio RAPOSO, 2020, "Bottom-up creativity and insurgent citizenship in 'Afro Lisboa': Racial difference and cultural commodification in Portugal”, Cultural Dynamics, 32 (4): 328-352.

CASTLEMAN, Craig, 1982, Getting Up: Subway Graffiti in New York. Cambridge, MA: The MIT Press.

CRESSWELL, Tim, 1992, “The crucial 'where' of graffiti: a geographical analysis of reactions to graffiti in New York”, Environment and Planning D: Society and Space, 10 (3): 329-344. ECKERT, Cornelia, e Ana Luiza ROCHA, 2013, Etnografia de Rua: Estudos de Antropologia Urbana. Porto Alegre: UFRGS.

EVANS, Graeme, 2016, "Graffiti, art and the city: from piece-making to place-making", in Jeffrey Ian Ross (ed.), Routledge Handbook of Graffiti and Street Art, Londres e Nova Iorque: Routledge, 168-182.

FERRELL, Jeff, 1996, Crimes of Style: Urban Graffiti and the Politics of Criminality. Boston, MA: Northeastern University Press. 
FERro, Lígia, 2016, Da Rua para o Mundo: Etnografia Urbana Comparada do Graffiti e do Parkour. Lisboa: Imprensa de Ciências Sociais.

FERro, Lígia, Pedro OliveIRA, Sara TRINDADE, e Susana PEIXOTO, 2014, "Vive o bairro! A intervenção comunitária como ferramenta da redução de riscos e minimização de danos na Matriz H do Bairro da Flamenga”, Forum Sociológico, 25 (1): 63-72.

FIGUEROA SAAVEDRA, Fernando, 2006, Graphitfragen: Una Mirada Reflexiva sobre el Graffiti. Madrid: Ediciones Minotauro Digital.

FLORIDA, Richard, 2011, A Ascensão da Classe Criativa. Porto Alegre: L\&PM.

GUINARD, Pauline, e Antonin MARGIER, 2018 , "Art as a new urban norm: Between normalization of the City through art and normalization of art through the City in Montreal and Johannesburg", Cities, 77: 13-20.

GRONDEAU, Alexandre, e Florence PONDAVEN, 2018, "Le street art, outil de valorisation territoriale et touristique: l'exemple de la Galeria de Arte Urbana de Lisbonne", EchoGéo, 44. Disponível em < http://journals.openedition.org/ > (última consulta em outubro 2021).

INGLIS, David, 2005, “Thinking 'art' sociologically”, in David Inglis e John Hughson (eds.), The Sociology of Art: Ways of Seeing. Nova Iorque: Palgrave Macmillan.

JAŻDŻEWSKA, Iwona, 2017, "Murals as a tourist attraction in a post-industrial city: a case study of Łódż (Poland)”, Tourism, 27 (2): 45-56

LANDRY, Charles, 2000, The Creative City: A Toolkit for Urban Innovators. Londres: Comedia and Earthscan.

LOUKAITOU-SIDERIS, Anastasia, e Konstantina SOURELI, 2012, "Cultural tourism as an economic development strategy for ethnic neighborhoods”, Economic Development Quarterly, 26 (1): 50-72.

MACDONALD, Nancy, 2001, The Graffiti Subculture: Youth, Masculinity and Identity in London and New York. Nova Iorque: Palgrave Macmillan.

MCAULIFFE, Cameron, 2012, "Graffiti or street art? Negotiating the moral geographies of the creative city", Journal of Urban Affairs, 34 (2): 189-206.

MIGUEL-MOLINA, María de, Virginia SANTAMARINA-CAMPOS, Blanca de MIGUEL-MOLINA, e María del Val SEGARRA-OÑA, 2013, "Creative cities and sustainable development: mural-based tourism as a local public strategy", Dirección y Organización, 50: 31-36.

MOKRAS-GRABOWSKA, Justyna, 2014, "Art-tourism space in Łodz: the example of the Urban Forms Gallery”, Tourism, 24 (2): 23-30.

MOULD, Oli, 2015, Urban Subversion and the Creative City. Abingdon, Oxon; New York, NY: Routledge.

PAVONI, Andrea, 2019, "Speculating on (the) urban (of) art: (un)siting street art in the age of neoliberal urbanization”, Horizontes Antropológicos, 25 (55): 51-88.

PEREIRA, Alexandre Barbosa, 2012, "Quem não é visto, não é lembrado: sociabilidade, escrita, visibilidade e memória na São Paulo da pichação”, Cadernos de Arte e Antropologia, 1: 55-69.

PEREIRA, Alexandre Barbosa, 2016, "Visibilidade e escrita de si nos riscos do pixo paulistano", Revista de Ciências Sociais, 47 (1): 77-100.

PUSSETTI, Chiara, e Vitor BARROS, 2019, "O terceiro lado do muro: a arte e as suas cidades", Fórum Sociológico, 35: 51-59.

RAPOSO, Otávio, 2018, "Guias da periferia: usos da arte urbana num bairro precarizado de Lisboa”, in Renata de Sá Gonçalves e Lígia Ferro (orgs.), Cidades em Mudança: Processos Participativos em Portugal e no Brasil. Rio de Janeiro: Editora Mauad X, 127-144. 
RAPOSO, Otávio, 2019, “The reinvention of a peripheral neighborhood in Lisbon: reflections on urban art, ethnography and public policy”, in Lígia Ferro e David Poveda (eds.), Arts and Ethnography in a Contemporary World: From Learning to Social Participation. Londres, Tufnell Press.

RAPOSO, Otávio, e Guillermo ADERALDO, 2019, "Políticas públicas e produção artístico-cultural entre jovens das periferias de Lisboa e São Paulo", Etnográfica, 23 (1): 109-132.

RAPOSO, Otávio, Rita ALVES, Pedro VARElA, e Cristina ROLDÃO, 2019, "Negro drama: racismo, segregação e violência policial nas periferias de Lisboa”, Revista Crítica de Ciências Sociais, 119, 5-28.

ROSS, Jeffrey Ian, 2016a, Routledge Handbook of Graffiti and Street Art. Londres e Nova Iorque: Routledge.

ROSS, Jeffrey Ian, 2016b, "How major urban centers in the United States respond to graffiti/street art", in Jeffrey Ian Ross, Routledge Handbook of Graffiti and Street Art. Londres e Nova Iorque: Routledge, 393-403.

SCHACTER, Rafael, 2014, "The ugly truth: street art, graffiti and the creative city", Art \& the Public Sphere, 3 (2): 161-176.

SHAPIRO, Roberta, 2012, "Avant-propos", in Roberto Shapiro e Nathalie Heinich (orgs.), De l'artification: enquêtes sur le passage à l'art. Paris: EHESS, 20-21.

SHAPIRO, Roberta, 2019, "Artification as process", Cultural Sociology 13(3): 265-275

WACLAWEK, Anna, 2011, Graffiti and Street Art. Londres: Thames \& Hudson.

WEISS, Marc, 2018, "Global Urban Development (GUD) in Brazil: The Porto Alegre Sustainable Innovation Zone (ZISPOA) and Urban Thinkers Campus”, World Urban Campaign Newsletter, UN-Habitat. Disponível em < https://e3591706-77 1 1-4e9a-ad37-2228 f17ebdf2.filesusr.com/ugd/be81dl_6841235d64634d2892777c24302be290.pdf > (última consulta em outubro de 2021).

WELLS, Maya Morgan, 2016, "Graffiti, street art, and the evolution of the art market", in Jeffrey Ian Ross (ed.), Routledge Handbook of Graffiti and Street Art. Londres e Nova Iorque: Routledge, 464-474.

YÚDICE, George, 2004, A Conveniência da Cultura: Usos da Cultura na Era Global. Belo Horizonte: Editora UFMG.

ZUKIN, Sharon, 1995, The Cultures of Cities. Oxford: Blackwell. 